Article

\title{
Supplementary Light Source Affects Growth and Development of Carnation 'Dreambyul' Cuttings
}

\author{
Mengzhao Wang ${ }^{1}$, Jie Xiao ${ }^{1}$, Hao Wei ${ }^{1} \mathbb{D}$ and Byoung Ryong Jeong $1,2,3, * \mathbb{C}$ \\ 1 Department of Horticulture, Division of Applied Life Science (BK21 Plus Program), Graduate School of \\ Gyeongsang National University, Jinju 52828, Korea; meng.zhao@163.com (M.W.); xiaojsicau@163.com (J.X.); \\ oahiew@gmail.com (H.W.) \\ 2 Institute of Agriculture \& Life Science, Gyeongsang National University, Jinju 52828, Korea \\ 3 Research Institute of Life Science, Gyeongsang National University, Jinju 52828, Korea \\ * Correspondence: brjeong@gnu.ac.kr; Tel.: +82-55-772-1913
}

Received: 22 July 2020; Accepted: 17 August 2020; Published: 18 August 2020

check for updates

\begin{abstract}
Carnation (Dianthus caryophyllus L.) is a major floricultural crop, cultivated widely for cut flowers. This study was conducted to determine the optimal supplementary light source for the cutting propagation of carnation 'Dreambyul' cuttings. Terminal cuttings were propagated in a glasshouse with an average of $260 \mu \mathrm{mol} \cdot \mathrm{m}^{-2} \cdot \mathrm{s}^{-1}$ photosynthetic photon flux density (PPFD) coming from the sun (the control), supplemented with one of three artificial light sources: mixed (red: blue: white $=6: 1: 1$ ) light-emitting diodes (LED-mix), metal halide $(\mathrm{MH})$ lamps, or high-pressure sodium (HPS) lamps. The supplementary light was provided from 7:00 to 17:00 $\mathrm{h}$ at $100 \mu \mathrm{mol} \cdot \mathrm{m}^{-2} \cdot \mathrm{s}^{-1} \mathrm{PPFD}$ during propagation. The cuttings were kept on a fogged bench in a glasshouse for 25 days with $24 / 15{ }^{\circ} \mathrm{C}$ day/night temperatures and $88 \%$ relative humidity. Compared with the control, better root formation was observed from cuttings grown under the supplementary lights after 10 days. After 25 days of propagation, MH significantly increased the root length, root number, root fresh and dry weights, and shoot biomass, shoot length, and shoot fresh and dry weights. The best root ball formation and the highest root activities were also found in cuttings propagated with supplementary MH light. Supplementary light increased the plant temperature, quantum yield, stomatal conductance, and the contents of chlorophyll, soluble proteins, and carbohydrates. Overall, the root formation and development of carnation 'Dreambyul' cuttings were significantly promoted by the three supplementary light sources. Of the three, MH was identified as the optimal supplementary light source.
\end{abstract}

Keywords: adventitious root formation; artificial light; biomass; quantum yield; root activities

\section{Introduction}

The economic value of ornamental plants has increased significantly worldwide, by $8-10 \%$ annually [1]. After rose, the most sought-after species in the global market is carnation (Dianthus caryophyllus L.), due to its excellent characteristics [2]. In Korea, carnations were cultivated over 42.9 hectares, with the total market value of 6.7 billion KRW in 2016 [3]. Carnations in the Korean market have a wide range of attractive shapes, colors, sizes, and delicate fragrances [4].

Vegetative propagation is common and rapid for several ornamental plant species. It retains the genetic traits of stock plants by creating clones with the same characteristics [5]. Efficient adventitious rooting is a key process in the vegetative propagation of horticultural species. Well-rooted cuttings are a requisite for the optimal growth of high-quality plants. Carnation is primarily propagated as cuttings in Korea [6], and profitable carnation cultivars are propagated from terminal stem cuttings collected from elite mother plants [7]. Several studies have investigated internal and external factors that affect 
the rooting of carnation cuttings during propagation. Such factors include the rooting substrate [8], rooting hormones [9], propagation season [10], cutting types [11], and endogenous hormone levels in stem cuttings [12]. However, not many studies have been conducted to investigate the effects of light on the rooting of carnation cuttings during the propagation process.

Light is the foremost energy source for plant growth. Supplementary lights are broadly used in agricultural production for the advancement in crop growth, yield, and quality, which has been confirmed by many researchers [13-15].

In a glasshouse, the daily light integral (DLI) may be reduced by the glazing materials, interior structures, and hanging baskets suspended above benches. Supplementary light is the only way to substantially increase the DLI in such environments [16], and it has been used to enhance plant growth and development in horticulture [17]. Supplementary lighting can aid plant growth by providing the necessary light when insufficient natural light is present in a greenhouse. Improving the light conditions in greenhouses and optimizing the phytochemical concentrations in vegetables produced in controlled environments enhance the growth and yield [18]. Therefore, supplementary lighting is an important horticultural strategy to improve crop growth, maintain high yields all year round, and produce superior-quality plants $[19,20]$. The morphology, physiology, biochemistry, and transcriptional expression vary in the light spectrum [21-23]. Changes in the light spectrum can affect the leaf structure, palisade mesophyll cell thickness, and epidermis [24,25]. The supplementary light source is a key factor of the changes in the light spectrum. High-pressure sodium (HPS) and metal halide $(\mathrm{MH})$ lamps are two conventional artificial light sources commonly applied in greenhouse horticulture due to their long service life, reasonable light spectrum, and low price [24,26-28]. Light-emitting diodes (LEDs) have gained widespread attention, since they provide a narrow wavelength band with a high efficiency [29-31]. However, data are still scarce regarding the choice of the light source and how the supplementary light source influences the adventitious rooting of carnations during cutting propagation.

This work aimed to study the effects of supplementary light provided by LED-mix, MH, and HPS on carnation cuttings and identify the optimal supplementary light source for greenhouse cutting propagation of carnations.

\section{Materials and Methods}

\subsection{Plant Materials and Culture Conditions}

The mother plants of carnation 'Dreambyul' used in the study were acclimated after micropropagation in vitro and then grown in a Venlo-type glasshouse $\left(35^{\circ} 09^{\prime} \mathrm{N}, 128^{\circ} 06^{\prime} \mathrm{E}\right.$, Jinju, Korea) for 3 months. Then terminal cuttings from these mother plants were harvested and stuck in 128 square-cell plug trays containing a commercial BVB medium (Bas Van Buuren Substrates, EN-12580, De Lier, The Netherlands). The cuttings were kept on a mist (fogged for 30 min every $30 \mathrm{~min}$ ) propagation bench with a mean air temperature of $24 / 15^{\circ} \mathrm{C}$ day/night and relative humidity of $88 \%$ in a Venlo-type glasshouse with an average daily light intensity of $260 \mu \mathrm{mol} \cdot \mathrm{m}^{-2} \cdot \mathrm{s}^{-1}$ photosynthetic photon flux density (PPFD) coming from the sun. The daily light integral (DLI) was $9.36 \mathrm{~mol} \cdot \mathrm{m}^{-2} \cdot \mathrm{d}^{-1}$. This experiment was carried out from 22 October to 16 November 2019.

\subsection{Supplementary Light Treatments}

This study used mixed (red: blue: white $=6: 1: 1$ ) light-emitting diodes (LED-mix, FL300, Senmatic A/S, Søndersø, Denmark), metal halide lamps (MH, SunLumen Lighting, Gyeongju, Korea), and high-pressure sodium lamps (HPS, BLV Licht- und Vakuumtechnik, Steinhöring, Germany) as supplementary light sources, and a group without any supplementary light was set as the control. The lamps were placed above the bench, and the supplementary light intensity was set at $100 \mu \mathrm{mol} \cdot \mathrm{m}^{-2} \cdot \mathrm{s}^{-1}$ PPFD from 07:00 to 17:00 by adjusting the position of the lamps after measuring multipoint averages in each treatment area. The supplementary light intensity was measured with a 
quantum radiation probe (FLA 623 PS, ALMEMO, Holzkirchen, Germany) at the top leaf level of the cuttings at night to avoid the effects of sunlight, and the spectrum of the light sources was measured with spectroradiometers (International Light Technologies, Peabody, MA, USA). The experiment was laid out in a completely randomized design with three replications per treatment, and the treatment locations in a controlled environment were randomly laid out in order to minimize location effects. In addition, enough space was reserved, and two layers of 0.3 -mm-thick black non-woven fabric curtain was used between lamps to prevent light from one treatment from interacting with another treatment.

\subsection{Measurement of Plant Temperatures}

Before the end of the experiment, infrared measurements with a thermographic camera (testo 882, Testo SE \& Co. KGaA, Titisee-Neustadt, Germany) were taken to estimate the plant temperature on a sunny day. The thermograms were taken $1 \mathrm{~m}$ above the cuttings at 13:00 when the supplementary light was on and were analyzed with IRSoft (version 4.6; available online: https://www.testo.com/en/ services/download).

\subsection{Determine of Root Activities}

To determine the root activities, $0.5 \mathrm{~g}$ of fresh roots were completely immersed in a solution containing $5 \mathrm{~mL}$ of $0.4 \%$ triphenyl-tetrazolium chloride (TTC) and $5 \mathrm{~mL}$ of $66 \mathrm{mmol} \cdot \mathrm{L}^{-1}$ phosphate buffer ( $\mathrm{pH}$ 7.0). The fresh roots were then incubated at $37^{\circ} \mathrm{C}$ for $3 \mathrm{~h}$, and $2 \mathrm{~mL}$ of $1 \mathrm{~mol} \cdot \mathrm{L}^{-1} \mathrm{H}_{2} \mathrm{SO}_{4}$ was subsequently added to end the reaction. The roots were then taken out and the moisture was carefully wiped off. The roots were then thoroughly ground with $3 \mathrm{~mL}$ of ethyl acetate and a small amount of quartz sand to extract triphenyl formazan. After filtering the red extract into a 10-mL volumetric flask, the residue was washed 3 times with $2 \mathrm{~mL}$ of ethyl acetate before being added to the volumetric flask, and then the volume of the solution was brought up to $10 \mathrm{~mL}$ with ethyl acetate. The absorbance at $485 \mathrm{~nm}$ was recorded with a UV spectrophotometer (Libra S22, Biochrom Ltd., Cambridge, UK). The root activities were expressed as the amount of TTC reduction $(\mu \mathrm{g})$ per $\mathrm{g}$ of root fresh weight per hour.

\subsection{Stomatal Conductance and Plant Chlorophyll Fluorescence}

The stomatal conductance and photosynthesis were sampled and averaged from three cuttings within each repetition. Measurements were taken on fully expanded leaves after $2 \mathrm{~h}$ of the supplementary light treatments. The stomatal conductance was assessed using a Decagon Leaf Porometer SC-1 (Decagon Device Inc., Pullman, WA, USA), and the photosynthesis was assessed with a FluorPen FP 100 (Photon Systems Instruments, PSI, Drásov, Czech Republic).

\subsection{Chlorophyll A and B, Soluble Protein, and Carbohydrate Analyses}

The contents of chlorophyll $a$ and $b$ were estimated according to the method described by Arnon [32] with some modifications. In brief, $0.1 \mathrm{~g}$ of fresh leaves were cut into small pieces and kept in $2.0 \mathrm{~mL}$ tubes, where $2 \mathrm{~mL}$ of $80 \%$ acetone was added. The tubes were wrapped with tin foil and kept in a $4{ }^{\circ} \mathrm{C}$ refrigerator for $12 \mathrm{~h}$ before extraction. The extract was centrifuged at $5000 \mathrm{rpm}$ for $10 \mathrm{~min}$, and the supernatant was transferred to a colorimeter tube, then the absorbance was measured at 645 and $663 \mathrm{~nm}$, against a buffer blank in a UV spectrophotometer. The contents of chlorophyll a and b were determined using the following equations:

$$
\begin{aligned}
& \text { Chlorophyll a }=\frac{(12.72 \times \text { OD at } 663 \mathrm{~nm}-2.59 \times \mathrm{OD} \text { at } 645 \mathrm{~nm}) \times \mathrm{V}}{\text { Sample fresh weight }} \\
& \text { Chlorophyll b }=\frac{(22.88 \times \text { OD at } 645 \mathrm{~nm}-4.67 \times \text { OD at } 663 \mathrm{~nm}) \times \mathrm{V}}{\text { Sample fresh weight }}
\end{aligned}
$$


The chlorophyll content was expressed as $\mathrm{mg}$ of chlorophyll per $\mathrm{g}$ of fresh leaf weight. The $\mathrm{V}$ is the volume of the extract solution.

Soluble proteins were extracted with a sodium phosphate buffer and measured calorimetrically using a Bradford Reagent (Sigma-Aldrich, St. Louis, MO, USA), according to Bradford's method [33]. The soluble sugar and starch contents were determined by the Anthrone colorimetric method according to Wei et al. [15].

\subsection{Measurements of Growth Parameters}

After 10 days of the supplementary light treatments, the mid-measurement was carried out to record the rooting ratio and compare the initial growth of roots and shoots of the cuttings. After 25 days of the supplementary light treatments, the cuttings treated with a supplementary light source had formed a well-developed root ball that was easily pulled out of the plug tray. At this stage, the final measurement of the growth parameters was collected. For measuring the growth parameters, whole cuttings were harvested, and roots were washed carefully using tap water. Growth parameters, such as the fresh weight, length, and the number of roots, were measured directly, whereas the dry weights of shoots and roots were measured after drying for $72 \mathrm{~h}$ at $60^{\circ} \mathrm{C}$ in an oven. The chlorophyll level was measured using a Plus Chlorophyll Meter (SPAD 502, Spectrum technologies, Korea). The cuttings were placed in liquid $\mathrm{N}_{2}$ in a $-80^{\circ} \mathrm{C}$ refrigerator for further analysis.

\subsection{Data Collection and Analysis}

The experimental assays used to obtain all results were repeated three times and are presented as the mean \pm standard error. The collected data were subjected to an analysis of variance (ANOVA) followed by Duncan's multiple range test at $p<0.05$ to find the statistical significance among the treatments by the Statistical Package for the Social Sciences version 21 (SPSS Inc., Chicago, IL, USA). All figures were made with the OriginPro software version 9.0 (OriginLab Corporation, Northampton, MA, USA).

\section{Results}

\subsection{Morphology and Growth Parameters Analysis}

Different supplementary light sources provide various spectral characteristics that may differ from those of sunlight. LED-mix consisted of a mixture of red, blue, and white lights that occupy a narrow spectrum with two peaks at 434 and $662 \mathrm{~nm}$ (Figure 1A). The accumulated irradiance was mainly distributed in red (62.8\%), blue (17.4\%), and green (18.2\%) lights (Table 1$)$. The MH lamps were white in appearance and strong emission lines were largely dispersed in all ranges with about 32.7 and $54.9 \%$ of the total irradiance focused on blue and green lights (Figure 1B, Table 1). The HPS lamps produced a characteristic golden-orange light, and the largest accumulated irradiance was mainly observed in green light (53.7\%), followed by red (36.5\%) and blue lights (6.2\%) (Table 1).
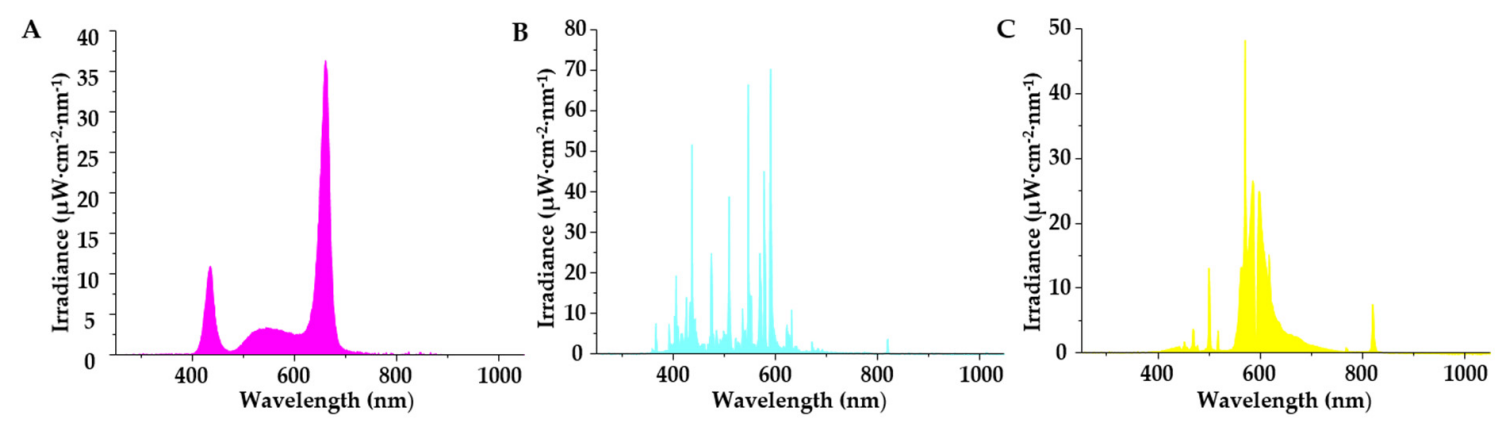

Figure 1. The spectral distribution of mixed (red: blue: white $=6: 1: 1)$ light-emitting diodes (LED-mix, (A)), metal halide lamps (MH, (B)), and high-pressure sodium lamps (HPS, (C)). 
Table 1. The irradiance distributions of the supplementary light sources: LED-mix, mixed (red: blue: white $=6: 1: 1$ ) light-emitting diodes; MH, metal halide lamps; and HPS, high-pressure sodium lamps.

\begin{tabular}{|c|c|c|c|c|c|c|}
\hline \multirow{2}{*}{$\begin{array}{l}\text { Supplementary } \\
\text { Light Source }\end{array}$} & \multicolumn{6}{|c|}{ Irradiance $\left(\mu W \cdot \mathrm{cm}^{-2}\right)$} \\
\hline & $\begin{array}{c}\text { UV } \\
(250-400 \mathrm{~nm})\end{array}$ & $\begin{array}{c}\text { Blue } \\
(401-500 \mathrm{~nm})\end{array}$ & $\begin{array}{c}\text { Green } \\
(501-600 \mathrm{~nm})\end{array}$ & $\begin{array}{c}\text { Red } \\
(601-700 \mathrm{~nm})\end{array}$ & $\begin{array}{c}\text { FR } \\
(701-800 \mathrm{~nm})\end{array}$ & $\begin{array}{c}\text { IR } \\
(801-1050 \mathrm{~nm})\end{array}$ \\
\hline LED-mix & 5.1 & 267.5 & 279.4 & 966.8 & 16.6 & 2.5 \\
\hline $\mathrm{MH}$ & 59.3 & 503.2 & 843.9 & 144.3 & 16.7 & 4.8 \\
\hline HPS & 0.9 & 89.8 & 783.9 & 532.9 & 37.9 & 14.2 \\
\hline
\end{tabular}

Observations revealed varied morphology differences in the roots of the cuttings after 10 days of propagation (Figure 2A). The rooting ratio was greatly influenced by the supplementary light source (Table 2). Cuttings supplied with MH light exhibited the highest rooting ratio (100\%), followed by those supplied with HPS light (91.7\%) and LED-mix light (75\%), while the control had lowest rooting ratio $(50 \%)$. There were no significant differences in the shoot length, shoot fresh and dry weights, chlorophyll level, and specific leaf weight among cuttings with or without supplementary light treatments. However, the roots of cuttings were vividly enhanced with supplementary light treatments, evidenced by the improvement in root parameters including the root length, number of roots, and root fresh and dry weights. Cuttings grown under MH light had the highest number of roots, followed by those grown under HPS light. The MH and HPS supplementary lights resulted in similar root fresh weights, but MH yielded the greatest root dry weight.

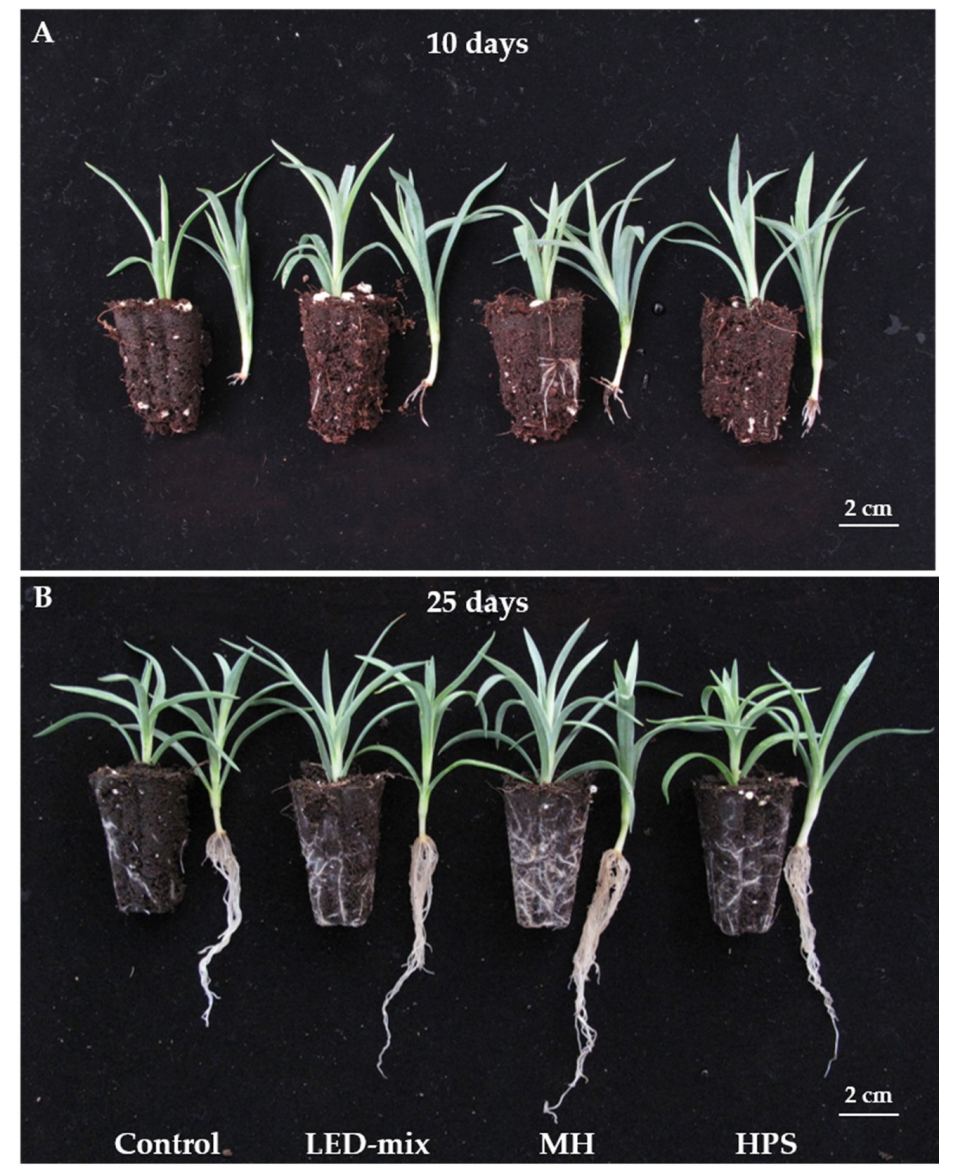

Figure 2. The morphology of carnation 'Dreambyul' cuttings affected by the supplementary light source after $10(\mathbf{A})$ and 25 days (B) of propagation. 
Table 2. The growth parameters, measured at 10 and 25 days after treatment initiation, of carnation 'Dreambyul' affected by the supplementary light source.

\begin{tabular}{|c|c|c|c|c|c|c|c|c|c|c|c|c|}
\hline \multirow[b]{2}{*}{$\begin{array}{l}\text { Cultivation } \\
\text { Duration }\end{array}$} & \multirow[b]{2}{*}{$\begin{array}{l}\text { Supplementary } \\
\text { Light Source }\end{array}$} & \multirow[b]{2}{*}{ Survival (\%) } & \multirow[b]{2}{*}{$\begin{array}{c}\text { Rooting } \\
(\%)\end{array}$} & \multicolumn{5}{|c|}{ Shoot } & \multicolumn{4}{|c|}{ Root } \\
\hline & & & & $\begin{array}{l}\text { Length } \\
\text { (cm) }\end{array}$ & $\begin{array}{l}\text { Fresh Weight } \\
\quad(\mathrm{mg})\end{array}$ & $\begin{array}{l}\text { Dry Weight } \\
\text { (mg) }\end{array}$ & $\begin{array}{l}\text { Chlorophyll } \\
\text { Level (SPAD) }\end{array}$ & 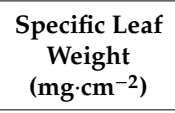 & $\begin{array}{l}\text { Length } \\
(\mathrm{cm})\end{array}$ & Number & $\begin{array}{c}\text { Fresh } \\
\text { Weight } \\
\text { (mg) }\end{array}$ & $\begin{array}{c}\text { Dry } \\
\text { Weight } \\
\text { (mg) }\end{array}$ \\
\hline \multirow{4}{*}{10 days } & Control & 100.0 & $50.0 c^{z}$ & 7.6 & 600.3 & 90.6 & 35.8 & 59.6 & $0.8 \mathrm{~b}$ & $8 c$ & $7.2 \mathrm{c}$ & $0.6 c$ \\
\hline & LED & 100.0 & $75.0 \mathrm{~b}$ & 7.7 & 633.3 & 100.5 & 33.2 & 60.8 & $1.4 \mathrm{a}$ & $10 \mathrm{~b}$ & $15.2 \mathrm{~b}$ & $1.7 \mathrm{~b}$ \\
\hline & MH & 100.0 & $100.0 \mathrm{a}$ & 7.8 & 676.7 & 104.1 & 37.4 & 60.8 & $1.6 \mathrm{a}$ & $16 \mathrm{a}$ & $19.6 \mathrm{a}$ & $2.2 \mathrm{a}$ \\
\hline & HPS & 100.0 & $91.7 \mathrm{ab}$ & 7.6 & 606.7 & 91.8 & 34.2 & 56.2 & $1.4 \mathrm{a}$ & $12 \mathrm{ab}$ & $17.7 \mathrm{a}$ & $1.8 \mathrm{~b}$ \\
\hline \multirow{4}{*}{25 days } & Control & 100.0 & 100.0 & 7.8 & 734.3 & $104.0 \mathrm{~b}$ & $38.1 \mathrm{~b}$ & 59.6 & $7.3 \mathrm{~b}$ & $20 \mathrm{~b}$ & $142.3 \mathrm{c}$ & $13.1 \mathrm{c}$ \\
\hline & LED & 100.0 & 100.0 & 8.1 & 750.6 & $117.6 \mathrm{ab}$ & $45.9 \mathrm{ab}$ & 57.0 & $7.9 \mathrm{ab}$ & $29 \mathrm{ab}$ & $173.7 \mathrm{~b}$ & $18.7 \mathrm{~b}$ \\
\hline & MH & 100.0 & 100.0 & 8.1 & 781.3 & $126.8 \mathrm{a}$ & $50.8 \mathrm{a}$ & 60.2 & $9.1 \mathrm{a}$ & $36 a$ & $267.8 \mathrm{a}$ & $28.7 \mathrm{a}$ \\
\hline & HPS & 100.0 & 100.0 & 8.0 & 738.5 & $104.1 \mathrm{~b}$ & $41.9 \mathrm{ab}$ & 57.9 & $8.0 \mathrm{ab}$ & $31 \mathrm{ab}$ & $199.4 \mathrm{ab}$ & $20.7 \mathrm{~b}$ \\
\hline
\end{tabular}

${ }^{\mathrm{Z}}$ Different letters indicate significant separation within columns by the Duncan's multiple range test at a 0.05 level. 
Furthermore, all cuttings grown with different treatments survived and rooted after 25 days of propagation (Table 2). However, cuttings grown with supplementary lights had a higher number and longer roots, as well as a better root ball formation compared to those in the control (Figure 2B). There were no differences observed in the shoot length, shoot fresh weight, and specific leaf weight of cuttings grown with the different supplementary light sources. However, the shoot dry weight was enhanced by $\mathrm{MH}$ light. Cuttings grown with supplementary light had higher chlorophyll contents than the control, with MH yielding the highest value, followed by LED-mix and HPS. Moreover, the root length, number of roots, and root fresh and dry weights were significantly increased for cuttings grown under the different supplementary lights. MH lamps resulted in the highest improvements of root parameters, followed by HPS lamps and LED-mix.

\subsection{Plant Temperature}

Thermal images of the cuttings under different treatments showed a huge difference (Figure 3A). The plant temperature was increased significantly by the supplementary light, and differences were observed among different supplementary light sources. The highest plant temperature was found in the cuttings under $\mathrm{MH}$ lamps, where the temperature ranged from $22.0^{\circ} \mathrm{C}$ to $31.8^{\circ} \mathrm{C}$ with an average temperature of $25.0^{\circ} \mathrm{C}$, which was $3.7^{\circ} \mathrm{C}$ higher than that of the control. The average plant temperature of cuttings exposed to HPS lamps and LED-mix were, respectively, $24.0^{\circ} \mathrm{C}$ and $22.6^{\circ} \mathrm{C}$, which were $2.7^{\circ} \mathrm{C}$ and $1.3^{\circ} \mathrm{C}$ higher than that of the control, respectively (Figure 3B).

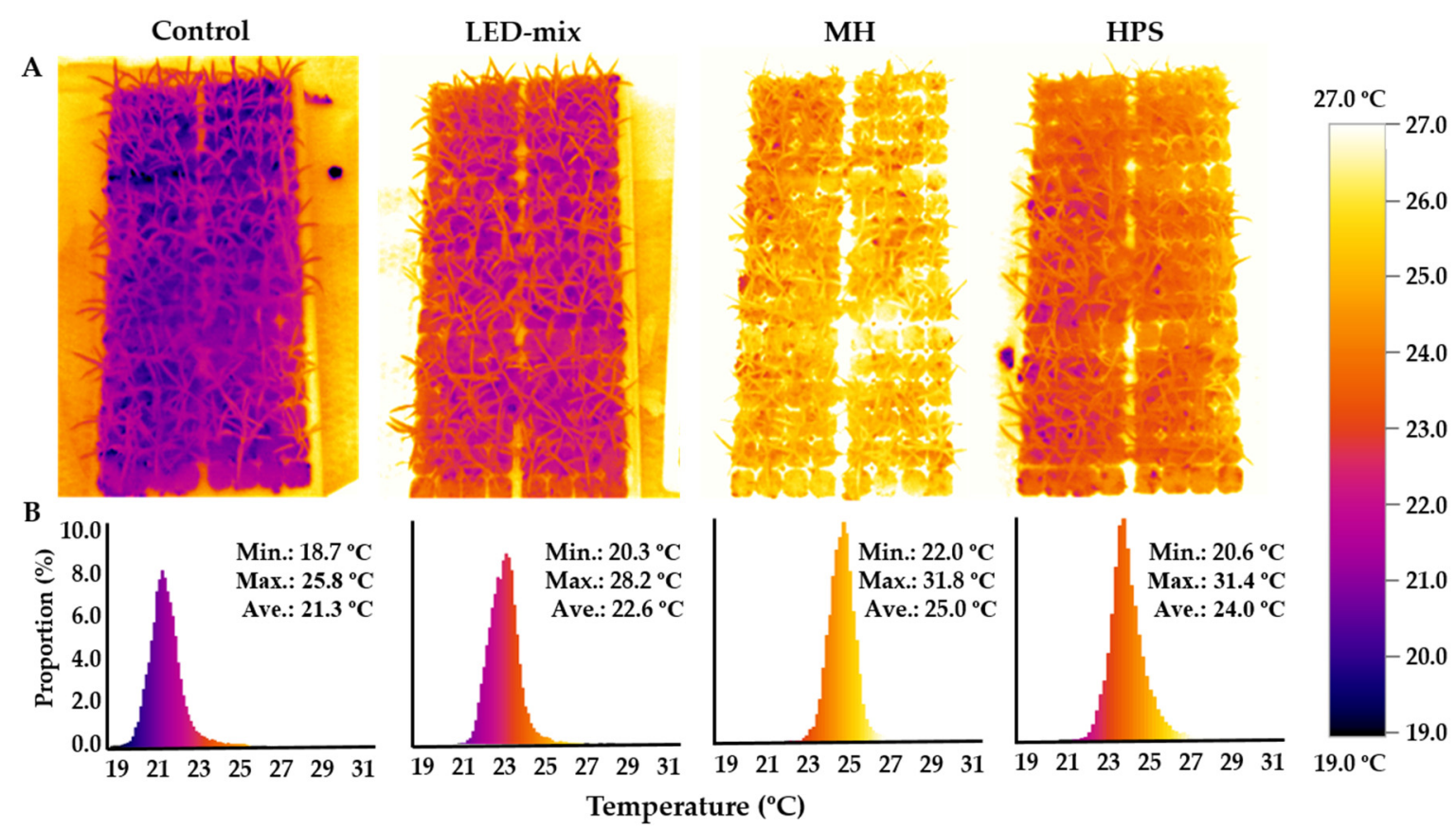

Figure 3. Thermal images of carnation 'Dreambyul' affected by the supplementary light source (A) and the temperature profiles (B). The images were taken $1 \mathrm{~m}$ above the cuttings at 13:00.

\subsection{Root Activities}

As shown in Figure 4, the root activities of the cuttings significantly increased with the supplementary light treatments. Cuttings grown with MH lamps had the highest root activities, while cuttings grown with LED-mix and HPS lamps displayed no significant differences and had a lower level of root activities. Cuttings in the control had the lowest level of root activities. 


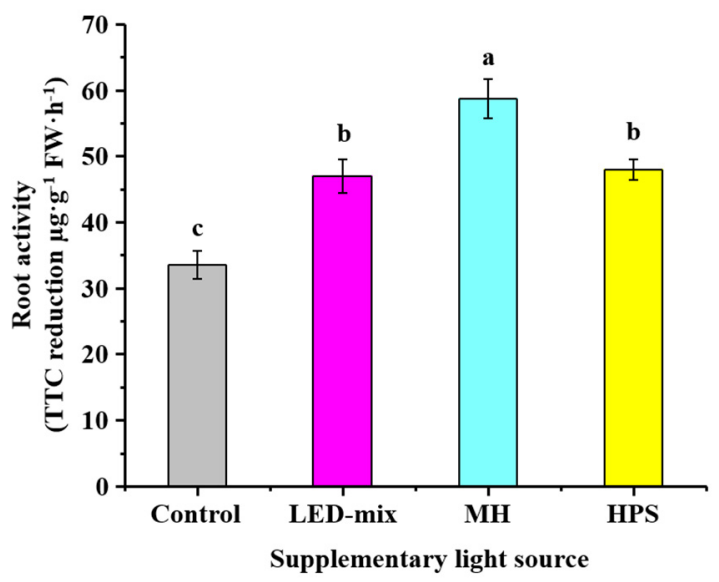

Figure 4. Effect of the supplementary light source on the root activities of carnation 'Dreambyul'. Data are shown as the mean \pm SEs, and different letters on the bars indicate significant differences according to the Duncan's multiple range test at $p \leq 0.05$.

\subsection{Quantum Yield and Stomatal Conductance}

The chlorophyll fluorescence ability was measured after the supplementary light treatments. The quantum yield $(\mathrm{Fv} / \mathrm{Fm})$ of cuttings treated with the supplementary lights were significantly promoted (Figure 5). The MH yielded the highest value (0.75), followed by LED-mix (0.73) and HPS (0.71). The control group exhibited the lowest quantum yield (0.67). Similar results were observed in the stomatal conductance of carnation 'Dreambyul' cuttings. The stomatal conductance was the greatest in cuttings grown with supplementary MH light, which was almost twice that of the control. The stomatal conductance of the cuttings grown with LED-mix and HPS lamps were 28.7 and $20.2 \mathrm{mmol} \cdot \mathrm{m}^{-2} \cdot \mathrm{s}^{-1}$ higher than that of the control, respectively (Figure 5).
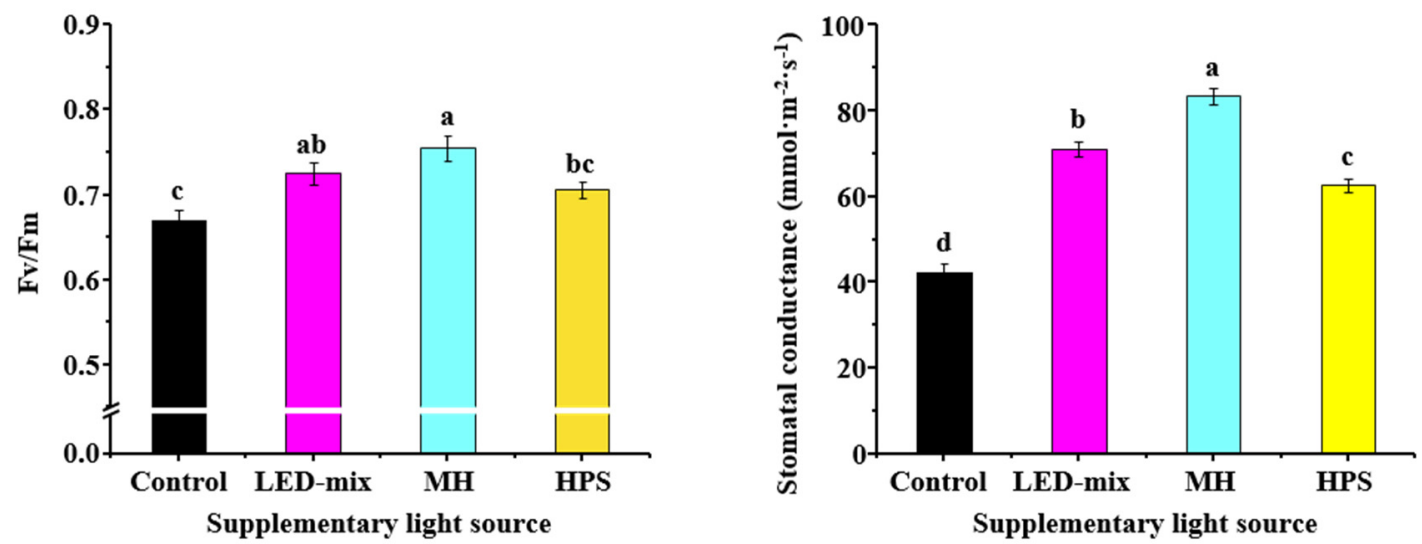

Figure 5. Effect of the supplementary light source on the quantum yield ( $\mathrm{Fv} / \mathrm{Fm})$ and the stomatal conductance of carnation 'Dreambyul'. Data are shown as mean \pm SEs, and different letters on the bars indicate significant differences according to the Duncan's multiple range test at $p \leq 0.05$.

\subsection{Chlorophyll $a$ and $b$, Soluble Proteins, and Carbohydrates Analyses}

The contents of chlorophyll a and b, carbohydrates, and soluble proteins were highly affected by the supplementary light source (Figure 6). The highest chlorophyll a and b contents were found in cuttings grown under MH lamps. The cuttings treated with HPS lamps had the lowest contents of chlorophyll $\mathrm{a}$ and $\mathrm{b}$ among those treated with the three supplementary light sources. The chlorophyll $\mathrm{a} / \mathrm{b}$ ratio in the control group was 2.0 , which was significantly lower than that of cuttings grown with the supplementary lights. However, the chlorophyll $a / b$ ratio of cuttings grown with the different supplementary light sources exhibited no significant differences. Soluble protein contents in leaves, 
stems, and roots were significantly higher for cuttings grown under $\mathrm{MH}$ lamps than those of the control. Cuttings grown with LED-mix had higher protein contents in the leaves but lower protein contents in the stems and roots compared to those grown with HPS lamps. For the contents of soluble sugars, no significant differences were observed in the stems among the four groups. The soluble sugar contents in the leaves and roots of cuttings were promoted by the supplementary lights, where MH yielded the highest level, followed by LED-mix and HPS. There were no significant differences in the starch content of stems among cuttings grown with the supplementary lights, which were higher compared to that of the control group. MH resulted in the highest starch content in leaves and roots, followed by LED-mix and HPS.
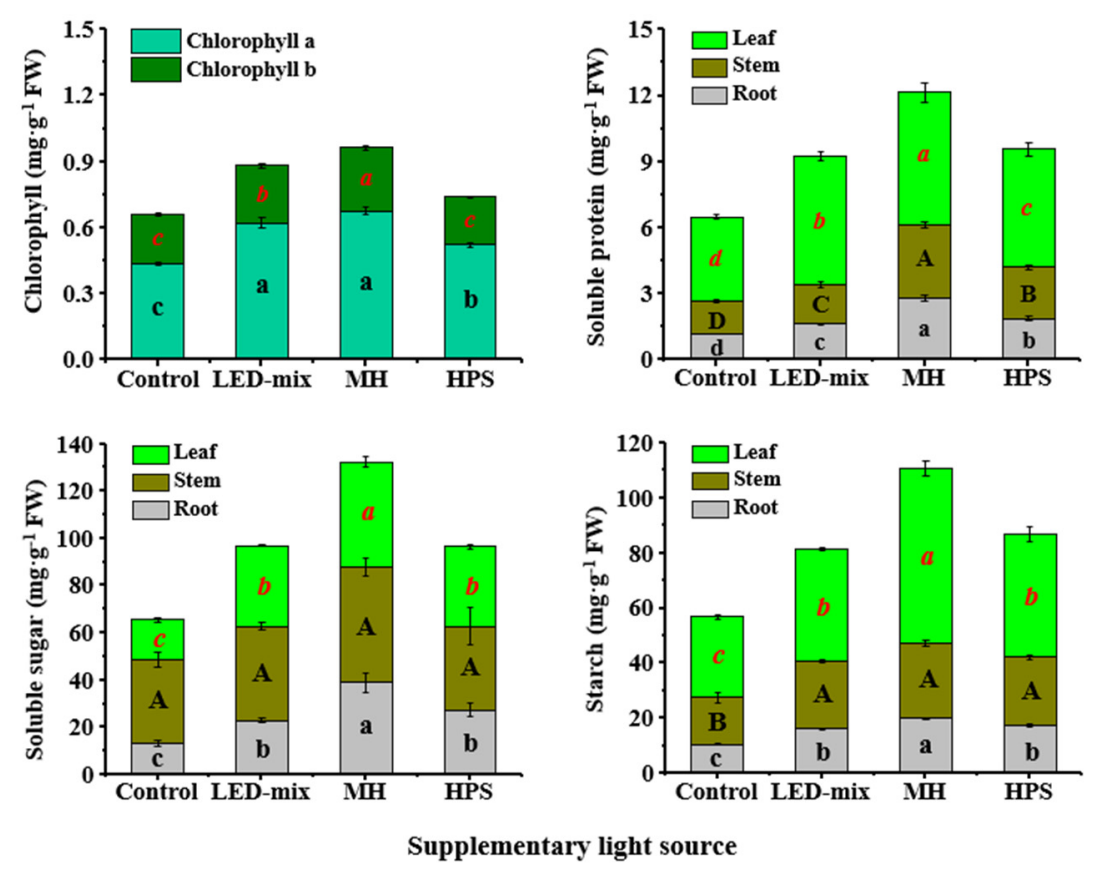

Figure 6. Effect of the supplementary light source on contents of chlorophyll a and b, soluble proteins, soluble sugars, and starch of carnation 'Dreambyul'. Data are shown as the mean \pm SEs, and different letters within columns indicate significant differences according to the Duncan's multiple range test at $p \leq 0.05$.

\section{Discussion}

Many studies have been conducted on in vitro or in vivo adventitious rooting utilizing diverse light qualities, but few studies have been done on in vivo adventitious rooting in greenhouses with the application of different supplementary light sources in daylight situations. Bielenin [34] found no significant differences in rooting for Juniperus and Thuja cuttings when supplementary lighting was provided at $20 \mu \mathrm{mol} \cdot \mathrm{m}^{-2} \cdot \mathrm{s}^{-1}$ PPFD. However, $70 \%$ red $+30 \%$ blue LEDs resulted in a somewhat enhanced root mass for Petunia when the supplementary light intensity was $70 \mu \mathrm{mol} \cdot \mathrm{m}^{-2} \cdot \mathrm{s}^{-1}$ PPFD [16]. In our study, $100 \mu \mathrm{mol} \cdot \mathrm{m}^{-2} \cdot \mathrm{s}^{-1}$ PPFD supplementary lighting from LED-mix, MH, or HPS lamps strongly enhanced the rooting of carnation 'Dreambyul'. After 10 days of propagation, all of the cuttings grown with supplementary MH lighting rooted and cuttings exposed to LED-mix and HPS rooted at a lower level, while the control group showed the weakest root formation, where only $50 \%$ of the cuttings rooted. Additionally, the use of supplementary light enhanced the root biomass, including root length, number, and fresh and dry weights, compared to control. Though all the cuttings survived and rooted after 25 days of cultivation, the cuttings propagated under the different supplementary lights had dramatically enhanced shoot and root biomasses. Moreover, they had developed a better root ball that was more suitable for transplanting. All the observations indicated that the utilization of 
supplementary lights could promote the growth and development of shoots and roots of carnation cuttings and shorten the cultivation duration.

It is reported that only 30 and $24 \%$ of the consumed electricity is converted to light by HPS and MH lamps, respectively, while the rest of the used electricity vanishes as heat [26,35]. Our results showed that when supplied at the same intensity, MH and HPS lamps resulted in a vividly increased plant temperature, compared to the control and LED-mix (Figure 3). Images taken at 10:00 and 16:00 showed similar results (data not shown). Temperature can potentially stimulate adventitious rooting by promoting the nutrient/water uptake and influencing certain enzymatic actions [36]. With some exceptions, the optimal rooting temperature would be between 20 and $30{ }^{\circ} \mathrm{C}$, and the number of roots, rooting ratio, and the speed of root formation increased with increasing temperature [37-39]. In this study, the heat released by MH lamps resulted in the highest average plant temperature, $3.7^{\circ} \mathrm{C}$ higher than that of the control. Cuttings grown with supplementary $\mathrm{MH}$ lighting had the highest shoot biomass, number of roots, root fresh and dry weights, and the fastest root formation. However, the plant temperature amplified by HPS was higher than LED-mix, but the shoot dry weight of cuttings grown under LED-mix was slightly higher than that of cuttings grown under HPS. In addition, there were no significant differences in the root number, length, and dry weight amongst the cuttings grown under LED-mix and HPS. This phenomenon may reflect an important role the light spectrum plays in addition to the temperature in the rooting and growth of cuttings. Rooting of Tsuru-rindo (Tripterospermum japonicum) cultured in vitro was promoted by red light but was inhibited by blue light [40]. On the other hand, Shin [41] observed that root growth was enhanced by blue light and hindered by red light for in-vitro-cultured Doritaenopsis plants. The contrary observations may indicate that the effects of the light spectrum on the root growth is species-dependent.

In terms of root physiology research, TTC reduction has been used extensively to differentiate between living and lifeless roots and vitality in plants [42-45]. TTC is colorless until it is reduced to triphenyl formazan, a bright red pigment that is simply extracted and photometrically measured [46]. Our study exhibited increased TTC reduction in all cuttings grown with supplementary lighting compared to that of the control, reflecting that supplementary light enhances root activities. The $\mathrm{MH}$ lamps induced the highest level of root activities among the three supplementary light sources, while no significant differences were observed in the root activities of cuttings grown with LED-mix and HPS. It was reported that the root activities are dependent on the soil temperature [47]. Our studies revealed MH lamps results in the highest ambient temperature around the cuttings, followed by HPS and LED-mix. However, the root activities of cuttings grown with supplementary HPS lighting was the same as those grown with LED-mix, which was consistent with how the two supplementary light sources affected the shoot and root biomasses. The results of the study leads us to conclude that the root activities were influenced by the combined effects of the temperature and light spectrum.

The Fv/Fm ratio, the maximum quantum yield of PSII photochemistry, is frequently used as an indicator of the photoinhibition or other kinds of stresses caused by the PSII system [48-50]. The Fv/Fm value of the vast majority of $C_{3}$ plants is from 0.8 to 0.84 under normal physiological conditions. When the $\mathrm{Fv} / \mathrm{Fm}$ value of plants is below this range, the plant is exposed to environmental stresses [51]. In our research, the supplementary light treatments increased the Fv/Fm value compared to the control. These results implied that MH, as well as LED-mix and HPS, had a positive effect on the photosynthetic efficiency compared to the control. Additionally, the cuttings grown under supplementary lights had a higher light utilization efficiency and a stronger ability to adapt to low-light conditions. However, the $\mathrm{Fv} / \mathrm{Fm}$ values presented in this study were lower than a healthy range, which implied that the cuttings were stressed. This could be explained by the light intensity during the cultivation period. The average daily light intensity of control (sunlight) and supplementary light, 260 and $360 \mu \mathrm{mol} \cdot \mathrm{m}^{-2} \cdot \mathrm{s}^{-1} \mathrm{PPFD}$, respectively, were lower than that in the growing season. A similar trend was observed in the change of the stomatal conductance. Stomata are important in regulating the gas exchange with the atmosphere and influence two basic physiological processes: photosynthesis and transpiration [52,53]. Previous studies have reported that a supplementary light source influences the formation, development, and 
functioning of stomata [54-56]. Compared with red light, blue light increased the stomatal conductance in Cordyline australis, Ficus benjamina, and Sinningia speciosa [57]. An increasing share of blue light also amplified the stomatal conductance and the net photosynthetic rate in Alternanthera brasiliana [24]. Consistent with the results of previous studies, the highest upsurge of stomatal conductance was found with supplementary MH lighting, followed by LED-mix and HPS. MH lamps had the highest proportion of blue light, followed by LED-mix and HPS.

Plant pigments have specific wavelength absorption patterns known as the absorption spectra, and biosynthetic wavelengths for the production of plant pigments are referred to as the action spectra [22]. Cuttings grown under all supplementary light treatments displayed a higher chlorophyll a content, as it has a wider spectrum compared to that of chlorophyll b. Chlorophyll a is what enables photosynthesis [58]. Compared with HPS, MH and LED-mix used in the current study had a higher proportion of blue light, which lead to an increase in the chlorophyll content, which agrees with the results of previous studies that blue light is favorable to chlorophyll formation [22,59]. Furthermore, we found that the chlorophyll $\mathrm{a} / \mathrm{b}$ ratio was largely increased with the application of supplementary light. This was in agreement with the reports that plants grown under high-intensity lights and the sun exhibit larger ratios of chlorophyll a/b than plants grown under a low light intensity $[60,61]$, and the ratio increased with higher light intensity during growth [62,63].

An increased rooting capacity is related to an upsurge in the synthesis of soluble proteins during the root regeneration process [64]. Adventitious rooting relies on an adequate supply of carbohydrates in the root regeneration zone, where they can encourage root instigation and expansion $[65,66]$. In this study, the contents of soluble proteins, soluble sugars, and starch in leaves, stems, and roots were measured. The trends in soluble proteins and carbohydrates in the cuttings were similar to those of the root biomass and root activities (Figure 6 and Table 2). Light-especially red and blue-can stimulate photosynthetic enzyme activities and improves stomatal opening, which is the foundation of photosynthesis [67]. Compared to HPS lamps, MH and LED-mix provide a higher percentage of red and blue lights, which resulted in a greater increase of soluble proteins and carbohydrates. Terfa et al. [68] showed higher levels of soluble carbohydrates in the plants grown under LEDs (red:blue $=8: 2$ ) than those grown under HPS in Rosa $\times$ hybrid. However, a logical, rigorous mechanism to discover the impact soluble proteins and carbohydrates have on adventitious rooting remains to be studied.

\section{Conclusions}

This study demonstrated that the application of supplementary light was very effective in improving the adventitious root formation during the propagation of carnation 'Dreambyul' cuttings. Application of supplementary light increased the plant temperature, quantum yield, stomatal conductance, chlorophyll a and b contents, root activities, as well as higher levels of soluble proteins and carbohydrates. The MH supplementary light was found to be the best to increase shoot and root biomasses, as well as accelerating root formation. Therefore, MH lamps can be strategically used to enhance the root formation during propagation of carnation cuttings.

Author Contributions: Conceptualization, B.R.J. and H.W.; methodology, B.R.J. and M.W.; software, M.W.; validation, B.R.J.; formal analysis, B.R.J. and M.W.; investigation, M.W. and J.X.; resources, B.R.J.; data curation, M.W. and J.X.; writing—original draft preparation, M.W.; writing-review and editing, B.R.J., M.W., H.W., and J.X.; visualization, M.W. and J.X.; supervision, B.R.J.; project administration, B.R.J. and M.W.; funding acquisition, B.R.J. and M.W. All authors have read and agreed to the published version of the manuscript.

Funding: This research was funded by the Korea Rural Development Administration (Project No. PJ01090805), M.W., J.X., and H.W. were supported by a scholarship from the BK21 Plus Program, Ministry of Education, Republic of Korea.

Conflicts of Interest: The authors declare no conflict of interest. 


\section{References}

1. Jain, S.M.; Ochatt, S.J. Protocols for In Vitro Propagation of Ornamental Plants; Springer: New York, NY, USA, 2010.

2. Sheela, V. Flowers for Trade; New India Publishing: New Delhi, India, 2008.

3. Nguyen, Q.H.; Thi, L.T.; Park, Y.G.; Jeong, B.R. Promoted growth and development of carnation plantlets in vitro by ventilation and combined red and blue light. Flower Res. J. 2018, 26, 166-178. [CrossRef]

4. Thi, L.T.; Park, Y.G.; Jeong, B.R. Growth and development of carnation 'Dreambyul' plantlets in a temporary immersion system and comparisons with conventional solid culture methods. In Vitro Cell. Dev. Biol. Anim. 2019, 55, 539-548. [CrossRef]

5. Christiaens, A.; Gobin, B.; Van Labeke, M. Light quality and adventitious rooting: A mini-review. Acta Hortic. 2016, 385-394. [CrossRef]

6. Lee, H.; Kim, S.; Chung, M.; Kim, C.; Chung, J. Effect of several culture conditions on growth of carnation propagules. Korean J. Hortic. Sci. 2006, 24, 392-397.

7. Agulló-Antón, M.Á.; Ferrández-Ayela, A.; Fernandez-Garcia, N.; Nicolás, C.; Albacete, A.; Pérez-Alfocea, F.; Sánchez-Bravo, J.; Pérez-Pérez, J.M.; Acosta, M. Early steps of adventitious rooting: Morphology, hormonal profiling and carbohydrate turnover in carnation stem cuttings. Physiol. Plant 2013, 150, 446-462. [CrossRef]

8. Wei, G.; Tang, N.; Wei, M.; Yan, H.; Han, Y. Effects of different substrates on root development of carnation cuttings. J. Qinghai Univ. 2017, 2, 007.

9. Gowda, P. Effect of indole butyric acid (IBA) on rooting of different carnation (Dianthus caryophyllus L.) genotypes. Int. J. Pure Appl. Biosci. 2017, 5, 1075-1080. [CrossRef]

10. Bharathy, P.; Sonawane, P.; Sasnu, P. Effect of plant growth regulators, type of cutting and season on rooting of carnation (Dianthus caryophyllus L.) cuttings. Indian J. Hortic. 2004, 61, 338-341.

11. Arvind, M.; Prince; Beniwal, V.; Sehrawat, S. Influence of auxins and types of cutting on rooting efficacy in carnation (Dianthus caryophyllus L.). Int. J. Pure App. Biosci. 2018, 6, 325-331.

12. Villanova, J.; Cano, A.; Albacete, A.; López, A.; Cano, E.Á.; Acosta, M.; Pérez-Pérez, J.M. Multiple factors influence adventitious rooting in carnation (Dianthus caryophyllus L.) stem cuttings. Plant. Growth Regul. 2016, 81, 511-521. [CrossRef]

13. Ren, X.; Liu, Y.; Jeong, H.K.; Jeong, B.R. Supplementary light source affects the growth and development of Codonopsis lanceolata seedlings. Int. J. Mol. Sci. 2018, 19, 3074. [CrossRef] [PubMed]

14. Liu, Y.; Ren, X.; Jeong, B.R. Supplementary light source affects growth, metabolism, and physiology of Adenophora triphylla (Thunb.) A.DC. seedlings. BioMed Res. Int. 2019, 2019, 1-16. [CrossRef]

15. Wei, H.; Wang, M.; Jeong, B.R. Effect of supplementary lighting duration on growth and activity of antioxidant enzymes in grafted watermelon seedlings. Agronomy 2020, 10, 337. [CrossRef]

16. Currey, C.J.; Lopez, R.G. Cuttings of Impatiens, Pelargonium, and Petunia propagated under light-emitting diodes and high-pressure sodium lamps have comparable growth, morphology, gas exchange, and post-transplant performance. HortScience 2013, 48, 428-434. [CrossRef]

17. Wallace, C.; Both, A.J. Evaluating operating characteristics of light sources for horticultural applications. Acta Hortic. 2016, 435-444. [CrossRef]

18. Samuolienè, G.; Sirtautas, R.; Brazaitytè, A.; Duchovskis, P. LED lighting and seasonality effects antioxidant properties of baby leaf lettuce. Food Chem. 2012, 134, 1494-1499. [CrossRef] [PubMed]

19. Li, Q.; Kubota, C. Effects of supplemental light quality on growth and phytochemicals of baby leaf lettuce. Environ. Exp. Bot. 2009, 67, 59-64. [CrossRef]

20. Zheng, L.; Van Labeke, M.-C. Effects of different irradiation levels of light quality on Chrysanthemum. Sci. Hortic. 2018, 233, 124-131. [CrossRef]

21. Haliapas, S.; Yupsanis, T.A.; Syros, T.D.; Kofidis, G.; Economou, A.S. Petunia $\times$ hybrida during transition to flowering as affected by light intensity and quality treatments. Acta Physiol. Plant 2008, 30, 807. [CrossRef]

22. Wang, H.; Gu, M.; Cui, J.; Shi, K.; Zhou, Y.; Yu, J. Effects of light quality on $\mathrm{CO}_{2}$ assimilation, chlorophyll-fluorescence quenching, expression of Calvin cycle genes and carbohydrate accumulation in Cucumis sativus. J. Photochem. Photobiol. B Biol. 2009, 96, 30-37. [CrossRef] 
23. Ma, L.; Li, J.; Qu, L.; Hager, J.; Chen, Z.; Zhao, H.; Deng, X.W. Light control of Arabidopsis development entails coordinated regulation of genome expression and cellular pathways. Plant Cell 2001, 13, $2589-2607$. [CrossRef] [PubMed]

24. Hogewoning, S.W.; Trouwborst, G.; Maljaars, H.; Poorter, H.; Van Ieperen, W.; Harbinson, J. Blue light dose-responses of leaf photosynthesis, morphology, and chemical composition of Cucumis sativus grown under different combinations of red and blue light. J. Exp. Bot. 2010, 61, 3107-3117. [CrossRef] [PubMed]

25. Macedo, A.F.; Leal-Costa, M.V.; Tavares, E.S.; Lage, C.L.S.; Esquibel, M.A. The effect of light quality on leaf production and development of in vitro-cultured plants of Alternanthera brasiliana Kuntze. Environ. Exp. Bot. 2011, 70, 43-50. [CrossRef]

26. Bian, Z.H.; Yang, Q.C.; Liu, W.K. Effects of light quality on the accumulation of phytochemicals in vegetables produced in controlled environments: A review. J. Sci. Food Agric. 2014, 95, 869-877. [CrossRef] [PubMed]

27. Gupta, S.D.; Jatothu, B. Fundamentals and applications of light-emitting diodes (LEDs) in in vitro plant growth and morphogenesis. Plant Biotechnol. Rep. 2013, 7, 211-220. [CrossRef]

28. Bergstrand, K.J.; Mortensen, L.M.; Suthaparan, A.; Gislerød, H.R. Acclimatisation of greenhouse crops to differing light quality. Sci. Hortic. 2016, 204,1-7. [CrossRef]

29. Yang, X.; Xu, H.; Shao, L.; Li, T.; Wang, Y.; Wang, R. Response of photosynthetic capacity of tomato leaves to different LED light wavelength. Environ. Exp. Bot. 2018, 150, 161-171. [CrossRef]

30. Duarte, J.H.; Costa, J. Blue light emitting diodes (LEDs) as an energy source in Chlorella fusca and Synechococcus nidulans cultures. Bioresour. Technol. 2018, 247, 1242-1245. [CrossRef]

31. Hasan, M.; Bashir, T.; Ghosh, R.; Lee, S.K.; Bae, H. An overview of LEDs' effects on the production of bioactive compounds and crop quality. Molecules 2017, 22, 1420. [CrossRef]

32. Arnon, D.I. Copper enzymes in isolated chloroplasts. Polyphenoloxidase in Beta vulgaris. Plant Physiol. 1949, 24, 1-15. [CrossRef]

33. Bradford, M.M. A rapid and sensitive method for the quantitation of microgram quantities of protein utilizing the principle of protein-dye binding. Anal. Biochem. 1976, 72, 248-254. [CrossRef]

34. Bielenin, M. Effect of red or blue supplementary light on rooting of cuttings and growth of young plants of Juniperus scopulorum 'Skyrocket' and Thuja occidentalis 'Smaragd'. Gartenbauwissenschaft 2000, 65, 195-198.

35. Viera, N. Watt About Interior Lighting: An Empirical Research Report. Available online: http://nickviera.com (accessed on 1 December 2007).

36. Geiss, G.; Gutierrez, L.; Bellini, C. Adventitious root formation: New insights and perspectives. Annu. Plant. Rev. Online 2018, 127-156. [CrossRef]

37. Gislerød, H.R. Physical conditions of propagation media and their influence on the rooting of cuttings. Plant Soil 1983, 75, 1-14. [CrossRef]

38. Howard, B.H. The influence of 4 (indolyl-3) butyric acid and basal temperature on the rooting of apple rootstock hardwood cuttings. J. Hortic. Sci. 1968, 43, 23-31. [CrossRef]

39. Friis, K. Rodning af Centradenia inaequilateralis 'Cascade'. Virkning af temperatur i rodningsmediet samt fungicidbehandling af moderplanter. Tidsskr. Planteavl 1987, 91, 263-267.

40. Moon, H.K.; Park, S.Y.; Kim, Y.W.; Kim, C.S. Growth of Tsuru-rindo (Tripterospermum japonicum) cultured in vitro under various sources of light-emitting diode (LED) irradiation. J. Plant Biol. 2006, 49, 174-179. [CrossRef]

41. Shin, K.S.; Murthy, H.N.; Heo, J.W.; Hahn, E.J.; Paek, K.Y. The effect of light quality on the growth and development of in vitro cultured Doritaenopsis plants. Acta Physiol. Plant 2008, 30, 339-343. [CrossRef]

42. Knievel, D.P. Procedure for estimating ratio of live to dead root dry matter in root core samples. Crop. Sci. 1973, 13, 124-126. [CrossRef]

43. Joslin, J.; Henderson, G. The determination of percentages of living tissue in woody fine root samples using triphenyltetrazolium chloride. For. Sci. 1984, 30, 965-970.

44. Caldwell, C.R. Estimation and analysis of cucumber (Cucumis sativus L.) leaf cellular heat sensitivity. Plant Physiol. 1993, 101, 939-945. [CrossRef] [PubMed]

45. Sulpice, R.; Gibon, Y.; Bouchereau, A.; Larher, F. Exogenously supplied glycine betaine in spinach and rapeseed leaf discs: Compatibility or non-compatibility? Plant Cell Environ. 1998, 21, 1285-1292. [CrossRef]

46. Steponkus, P.L.; Lanphear, F.O. Refinement of the triphenyl tetrazolium chloride method of determining cold injury. Plant. Physiol. 1967, 42, 1423-1426. [CrossRef] [PubMed] 
47. Lyr, H.; Garbe, V. Influence of root temperature on growth of Pinus sylvestris, Fagus sylvatica, Tilia cordata and Quercus robur. Trees 1995, 9, 220-223. [CrossRef]

48. Calatayud, A.; Alvarado, J.W.; Barreno, E. Differences in ozone sensitivity in three varieties of cabbage (Brassica oleracea L.) in the rural Mediterranean area. J. Plant Physiol. 2002, 159, 863-868. [CrossRef]

49. Guidi, L.; Nali, C.; Lorenzini, G.; Filippi, F.; Soldatini, G. Effect of chronic ozone fumigation on the photosynthetic process of poplar clones showing different sensitivity. Environ. Pollut. 2001, 113, 245-254. [CrossRef]

50. Krause, G.; Weis, E. Chlorophyll fluorescence and photosynthesis: The basics. Annu. Rev. Plant Biol. 1991, 42, 313-349. [CrossRef]

51. Fu, W.; Li, P.; Wu, Y. Effects of different light intensities on chlorophyll fluorescence characteristics and yield in lettuce. Sci. Hortic. 2012, 135, 45-51. [CrossRef]

52. Rui, Y.; Anderson, C.T. Functional analysis of cellulose and xyloglucan in the walls of stomatal guard cells of Arabidopsis. Plant Physiol. 2016, 170, 1398-1419. [CrossRef]

53. Fanourakis, D.; Giday, H.; Milla, R.; Pieruschka, R.; Kjaer, K.H.; Bolger, M.E.; Vasilevski, A.; Nunes-Nesi, A.; Fiorani, F.; Ottosen, C.-O. Pore size regulates operating stomatal conductance, while stomatal densities drive the partitioning of conductance between leaf sides. Ann. Bot. 2014, 115, 555-565. [CrossRef]

54. Jensen, N.B.; Clausen, M.R.; Kjaer, K.H. Spectral quality of supplementary LED grow light permanently alters stomatal functioning and chilling tolerance in basil (Ocimum basilicum L.). Sci. Hortic. 2018, 227, $38-47$. [CrossRef]

55. Vieira, L.D.N.; Fraga, H.P.D.F.; Dos Anjos, K.G.; Puttkammer, C.C.; Scherer, R.F.; Da Silva, D.A.; Guerra, M.P. Light-emitting diodes (LED) increase the stomata formation and chlorophyll content in Musa acuminata (AAA) 'Nanicão Corupá' in vitro plantlets. Theor. Exp. Plant. Physiol. 2015, 27, 91-98. [CrossRef]

56. Lee, S.H.; Tewari, R.K.; Hahn, E.J.; Paek, K.Y. Photon flux density and light quality induce changes in growth, stomatal development, photosynthesis and transpiration of Withania Somnifera (L.) Dunal. plantlets. Plant Cell Tissue Organ. Cult. 2007, 90, 141-151. [CrossRef]

57. Zheng, L.; Van Labeke, M.C. Long-term effects of red- and blue-light emitting diodes on leaf anatomy and photosynthetic efficiency of three ornamental pot plants. Front. Plant. Sci. 2017, 8, 917. [CrossRef] [PubMed]

58. Calatayud, A.; Barreno, E. Response to ozone in two lettuce varieties on chlorophyll a fluorescence, photosynthetic pigments and lipid peroxidation. Plant Physiol. Biochem. 2004, 42, 549-555. [CrossRef] [PubMed]

59. Fan, X.; Zang, J.; Xu, Z.-G.; Guo, S.; Jiao, X.; Liu, X.; Gao, Y. Effects of different light quality on growth, chlorophyll concentration and chlorophyll biosynthesis precursors of non-heading Chinese cabbage (Brassica campestris L.). Acta Physiol. Plant 2013, 35, 2721-2726. [CrossRef]

60. Melis, A.; Harvey, G. Regulation of photosystem stoichiometry, chlorophyll a and chlorophyll b content and relation to chloroplast ultrastructure. Biochim. Biophys. Acta 1981, 637, 138-145. [CrossRef]

61. Leong, T.Y.; Anderson, J.M. Adaptation of the thylakoid membranes of pea chloroplasts to light intensities. I. Study on the distribution of chlorophyll-protein complexes. Photosynth. Res. 1984, 5, 105-115. [CrossRef]

62. Senger, H.; Fleischhacker, P. Adaptation of the photosynthetic apparatus of Scenedesmus obliquus to strong and weak light conditions. I. Differences in pigments, photosynthetic capacity, quantum yield and dark reactions. Physiol. Plant 1978, 43, 35-42. [CrossRef]

63. Lichtenthaler, H.K.; Kuhn, G.; Prenzel, U.; Buschmann, C.; Meier, D. Adaptation of chloroplast-ultrastructure and of chlorophyll-protein levels to high-light and low-light growth conditions. Z. Naturforschung C 1982, 37, 464-475. [CrossRef]

64. Chu, E.P.; Tavares, A.R.; Kanashiro, S.; Giampaoli, P.; Yokota, E.S. Effects of auxins on soluble carbohydrates, starch and soluble protein content in Aechmea blanchetiana (Bromeliaceae) cultured in vitro. Sci. Hortic. 2010, 125, 451-455. [CrossRef]

65. Calamar, A.; De Klerk, G.J. Effect of sucrose on adventitious root regeneration in apple. Plant Cell Tissue Organ. Cult. (PCTOC) 2002, 70, 207-212. [CrossRef]

66. Li, M.; Leung, D.W. Starch accumulation is associated with adventitious root formation in hypocotyl cuttings of Pinus radiata. J. Plant Growth Regul. 2000, 19, 423-428. [CrossRef] 
67. Liu, Y.; Ren, X.; Jeong, B.R. Carbon dioxide enrichment combined with supplemental light improve growth and quality of plug seedlings of Astragalus membranaceus Bunge and Codonopsis lanceolata Benth. et Hook. $\mathrm{f}$. Agronomy 2019, 9, 715. [CrossRef]

68. Terfa, M.T.; Solhaug, K.A.; Gislerød, H.R.; Olsen, J.E.; Torre, S. A high proportion of blue light increases the photosynthesis capacity and leaf formation rate of Rosa $\times$ hybrida but does not affect time to flower opening. Physiol. Plant 2013, 148, 146-159. [CrossRef]

(c)

(C) 2020 by the authors. Licensee MDPI, Basel, Switzerland. This article is an open access article distributed under the terms and conditions of the Creative Commons Attribution (CC BY) license (http://creativecommons.org/licenses/by/4.0/). 